\title{
Production, water consumption and nutrient content of Chinese cabbage grown hydroponically in brackish water ${ }^{1}$
}

\author{
Produção, consumo hídrico e teores de nutrientes da couve chinesa cultivada \\ hidroponicamente com águas salobras
}

\author{
Raquele Mendes de Lira², Ênio Farias de França e Silva ${ }^{3}$, Gerônimo Ferreira da Silva**, Alexandre Nascimento \\ dos Santos $^{5}$ e Mário Monteiro Rolim 3
}

\begin{abstract}
Underground water reserves in the semi-arid region of Brazil are stored in the crystal formations that in large part have high concentrations of salt. However, the scarcity of this resource makes the use of this water necessary for various activities, including agriculture. The aim of this study was to evaluate the use of brackish water on the electrical conductivity and $\mathrm{pH}$ of the nutrient solution, and on the production, water consumption and the uptake of nutrients in Chinese cabbage (Brassica pekinensis L.) under a hydroponic system. The experimental design was completely randomised, with four replications and six levels of water salinity $\left(0.2,1.2,2.2,3.2,4.2\right.$ and $\left.5.2 \mathrm{dS} \mathrm{m}^{-1}\right)$, obtained by adding $\mathrm{NaCl}$ to the local water supply, with this water being used to prepare the nutrient solution and to make up the volume lost through evapotranspiration. The results showed that with the exception of the treatment at the lowest salinity, there was a tendency to increased electrical conductivity of the nutrient solution with the increasing salinity of the water; that the $\mathrm{pH}$ of the nutrient solution remained within the normal range throughout the cycle; that with the increasing salinity of the solution there was a reduction in all growth and production variables under analysis, in water consumption, and in leaf $\mathrm{N}, \mathrm{K}, \mathrm{Ca}$ and $\mathrm{Mg}$, and an increase in leaf concentrations of $\mathrm{Na}$ and $\mathrm{Cl}$. It is possible to use brackish water for the production of Chinese cabbage when grown hydroponically as an alternative for those producers who have an available supply of brackish water and a restricted supply of fresh water, however with a reduction in productivity.
\end{abstract}

Key words: Brassica pekinensis L.. Nutrient solution. Salinity. Mineral nutrition.

RESUMO - As reservas hídricas subterrâneas no Semiárido do Brasil estão armazenadas nas formações cristalinas que apresentam, em grande parte, elevadas concentrações salinas. Entretanto, a escassez do recurso obriga a utilização dessas águas para diversas atividades, inclusive a agricultura. Objetivou-se, com este trabalho, avaliar o emprego de águas salobras na condutividade elétrica e pH da solução nutritiva, na produção, no consumo hídrico e na extração de nutrientes, por couve chinesa (Brassica pekinensis L.), em sistema hidropônico. O delineamento experimental utilizado foi o inteiramente casualizado com quatro repetições e seis salinidades da água $(0,2 ; 1,2 ; 2,2 ; 3,2 ; 4,2$ e 5,2 dS m-1), obtidos pela adição de $\mathrm{NaCl}$ na água de abastecimento local, sendo estas águas utilizadas no preparo da solução nutritiva e na reposição do volume evapotranspirado. Verificou-se por meio dos resultados obtidos que, à exceção do tratamento de menor salinidade, nos demais tratamentos houve tendência de aumento da condutividade elétrica da solução nutritiva, com o incremento da salinidade da água; o pH da solução nutritiva permaneceu dentro da faixa de normalidade durante todo o ciclo; houve redução de todas as variáveis de crescimento e de rendimento analisadas, do consumo hídrico, dos teores foliares de $\mathrm{N}, \mathrm{K}, \mathrm{Ca}$ e $\mathrm{Mg}$ e, aumento nos teores foliares de $\mathrm{Na}$ e $\mathrm{Cl}$, com o aumento da salinidade da solução; é possível utilizar água salobra para a produção de couve chinesa, em cultivo hidropônico, como alternativa para produtores que tenham disponibilidade de água salobra e restrição à disponibilidade de água doce, porém com redução de produtividade.

Palavras-chave: Brassica pekinensis L.. Solução nutritiva. Salinidade. Nutrição mineral.

DOI: $10.5935 / 1806-6690.20150031$

*Autor para correspondência

${ }^{1}$ Recebido para publicação em 09/04/2014; aprovado em 30/03/2015

Parte da Dissertação de Mestrado da primeira autora apresentada ao Programa de Pós-Graduação em Engenharia Agrícola da Universidade Federal Rural de Pernambuco/UFRPE; Pesquisa financiada pelo CNPq e pelo INCTsal

${ }^{2}$ Programa de Pós-Graduação em Engenharia Agrícola, Departamento de Engenharia Agrícola/UFRPE, Recife-PE, Brasil, raquelelira@ gmail.com

${ }_{3}^{3}$ Departamento de Engenharia Agrícola/UFRPE, Recife-PE, Brasil, enio.silva@ deagri.ufrpe.br, rolim@deagri.ufrpe.br

${ }^{4}$ Programa de Pós-Graduação em Engenharia Agrícola, Departamento de Engenharia Agrícola//UFRPE, Rua Dom Manoel de Medeiros s/n,

Dois Irmãos, Recife-PE, Brasil, 52.171-900, agrogefe@yahoo.com.br

${ }^{5}$ Instituto Federal de Pernambuco, Barreiros-PE, Brasil, alexandrens14@yahoo.com.br 


\section{INTRODUCTION}

In Brazil, the semi-arid regions are the areas most affected by water shortages. These regions have reserves of ground water which can be used to meet the demand, however the water from these sources often has a high concentration of salts, which restricts its use for the irrigation of crops grown in the ground (ANDRADE JÚNIOR et al., 2006).

In light of this, hydroponics has emerged as an alternative technology, enabling the use of brackish water in crop production (SANTOS et al., 2010). The expansion of this cropping system has become a reality in Brazil in recent years and various researchers have joined forces so as to produce information which will contribute to the spread of this technique to the semi-arid region of north-eastern Brazil; the main focus of these studies being the relationship between plant production in hydroponic systems and the use of brackish water (GOMES et al., 2011; HOSSAIN; NONAMI, 2012; SANTOS et al., 2011; SOARES et al., 2013.).

In this type of cultivation, the level of salinity tolerated by crops is higher than in conventional farming due to the greater and constant availability of water and nutrients in the various types of hydroponic systems and the small or non-existent contribution the matric potential makes to the total water potential, with this representing a greater uptake of water and nutrients by the plants for the same quantity of salts (SOARES et al., 2007).

Given this hypothesis, crops in general, especially those of a short cycle, when grown in hydroponic systems should favour the use of brackish water, due to the lower exposure to salt stress reflecting directly in a reduction of the damage caused by such stress. So with the use of brackish water in hydroponics, it can expected that crops of interest be produced, such as the Chinese cabbage, with greater savings in water and input efficiency, lower environmental risk and less depletion of commercial revenue (MACIEL et al., 2012).

The Chinese cabbage also known as "nappa" cabbage, is very nutritious. It is an excellent source of folic acid (important for blood formation), vitamin A, the $\mathrm{B}$ vitamins, and calcium. It also provides vitamin $\mathrm{C}$ and mineral salts such as sodium, potassium, magnesium and calcium (EVANGELIST et al., 2009).

In Brazil, the use of Chinese cabbage in human food has been excessive, with a consumption of approximately $500 \mathrm{~g} \mathrm{person}^{-1}$ day $^{-1}$ (GORDIN et al., 2010). Nevertheless, information on production of the crop in hydroponic systems using brackish water is still relatively new or even non-existent in the country, this being reflected in a widespread lack of scientific studies related to the crop.

In this respect, the search for information on the use of brackish water in the hydroponic cultivation of Chinese cabbage becomes of fundamental importance to perfect investment in the hydroponic production of the crop, especially in the Brazilian semi-arid region. Furthermore, using this water in the production of the vegetable can be an alternative source of income for that farmer who can only count on the option of brackish water on his property.

In light of the above, this study aimed to evaluate the use of brackish water on the electrical conductivity and $\mathrm{pH}$ of the nutrient solution, and on the production, water consumption and nutrient uptake of Chinese cabbage in an NFT hydroponic system.

\section{MATERIAL AND METHODS}

The experiment was conducted at the Federal Rural University of Pernambuco (UFRPE), on the University Campus in Recife in the state of Pernambuco, Brazil (801'05" S, 3456’48” W; altitude $6.5 \mathrm{~m}$ ).

The research was carried out in a greenhouse having an arch-shaped cover of transparent, $0.10 \mathrm{~mm}$ thick polyethylene film of low density with anti-UV additive, $7.0 \mathrm{~m}$ wide and $24.0 \mathrm{~m}$ long, with a ceiling height of $3.0 \mathrm{~m}$ and height of $4.5 \mathrm{~m}$ at the centre. The front and side walls were made from screens with a $0.2 \mathrm{~m}$ baseboard of reinforced concrete.

A hydroponic structure was constructed comprising 24 plots. Each plot represented one independent NFT (nutrient film technique) hydroponic system, similar to that described by Soares et al. (2009), containing a plastic reservoir with a capacity of 60 litres and a $32 \mathrm{~W}, 220 \mathrm{~V}$ electric circulating pump. The structure consisted of hydroponic profiles of polypropylene, with a commercial diameter of $75 \mathrm{~mm}$, length of $3 \mathrm{~m}$ and holes of $25 \mathrm{~mm}$ radius, at a spacing of $0.25 \mathrm{~m}$ between plants by $0.30 \mathrm{~m}$ between profiles and with five plants per profile.

The profiles were installed at a height of $0.85 \mathrm{~m}$ with a $5 \%$ inclination to promote the flow and drainage of the solution. The injected solution ran down the profile slope at an average rate of $1.5 \mathrm{~L}$ per minute, the flow being regulated with the aid of a stopcock. Any surplus not injected into the profile returned to the reservoir through a return pipe, thus favouring aeration of the nutrient solution.

Individual automatic supply systems (of $15 \mathrm{~L}$ in volume) were also set up for each plot for the replacement of water lost by evapotranspiration, the dispensers consisting of a continuous section of PVC pipe with a diameter of $150 \mathrm{~mm}$, equipped with a graduated rule, fixed near a transparent hose for reading the water level, and connected to a ball cock, which automatically output water to the nutrient solution tank.

Seeds of Chinese cabbage were placed into $2 \times 2$ $\mathrm{x} 2 \mathrm{~cm}$ cells of phenolic foam to germinate, with three seeds per cell. After sowing, the phenolic foam plates 
were kept in a darkened environment until the seeds germinated, remaining in this environment for around 30 hours. The seedlings were then transferred to the NFT hydroponic nursery inside the greenhouse and irrigated with a 50\% diluted nutrient solution (FURLANI, 1998).

During the day, from 0700 to 1800 , irrigation of the nursery was controlled by an electric timer set for regular intervals of 15 minutes between each irrigation, also with a duration of 15 minutes. From 1800 to 0700 , the timer was programmed for one fifteen-minute irrigation every 2 hours.

At eight days after sowing (DAS), the plants were thinned, leaving only one plant per cell. The seedlings continued in the nursery for 15 DAS, and were then transplanted to the hydroponic profiles and submitted to the above treatments, together with the nutrient solution proposed by Furlani (1998) for leafy vegetables.

The experimental design was completely randomised with six treatments and four replications. The treatments comprised the salinities of the water $\left(0.2,1.2,2.2,3.2,4.2\right.$ and $\left.5.2 \mathrm{dS} \mathrm{m}^{-1}\right)$, defined on the basis of salinities used by Santos et al. (2010), as there are no studies on the Chinese cabbage in the literature. The water was produced by applying $\mathrm{NaCl}$ to the supply water until the desired electrical conductivity was reached using a conductivity meter, this water was then used to prepare the nutrient solution and to replace the volume lost by evapotranspiration.

Each type of water was prepared in a 500 L capacity tank, by measuring the electrical conductivity ( $\mathrm{ECW}$ ) and $\mathrm{pH}$ and then adding the macro and micronutrients to produce the nutrient solution, following recommendations proposed by Furlani (1998). To add the micronutrients, 1 Lof a 1,000x stock solution was prepared; an individual stock solution was made up for iron at the same proportion as the other micronutrients. After homogenisation, readings were taken of the $\mathrm{pH}$ and electrical conductivity of the solution (ECsol).

Data of temperature and relative humidity were collected daily inside the greenhouse for a period of 24 hours using a portable data logger, the temperature varying from 24.3 to $28.2{ }^{\circ} \mathrm{C}$ respectively for the minimum and maximum temperatures recorded. The relative humidity ranged from 74 to $86 \%$ respectively for the minimum and maximum humidity recorded. Readings of the ECsol and $\mathrm{pH}$ were also taken every other day. However, with a view to simulating real field conditions, and assuming that the farmer does not have the available material for such an adjustment, the $\mathrm{pH}$ was not corrected to the optimal range of 5.5 to 6.5. Replacement of the nutrient solution of the treatments was done whenever the ECsol of the control treatment reached a value of less than $1.0 \mathrm{dS} \mathrm{m}^{-1}$.

Plants were harvested every two weeks and separated into shoots and roots. The shoots were weighed on precision scales $(0.01 \mathrm{~g})$ to obtain the fresh matter production, and were then dried in a forced air circulation oven at $65{ }^{\circ} \mathrm{C}$ to constant weight, to get dry matter production. After drying and weighing, the leaves were ground to determine the levels of mineral nutrients, as recommended by Bezerra Neto and Barreto (2011).

Leaf area was determined from leaves scanned with the aid of computer software. The number of leaves per plant was obtained by counting them individually, and the absolute growth rate (AGR) and relative growth rate (RGR) for each harvest were obtained according to Benincasa (1988).

Water consumption per treatment, daily and throughout the cycle, was evaluated by means of readings taken by the automatic dispensers, and the volume of evapotranspiration subsequently calculated according to equation (1):

$V E t c=\underline{(R f-R i) \times \pi \times D^{2}} / 4 \times n \times \Delta T \times 10^{6}$

where: VEtc - volume of evapotranspiration, in mL plant ${ }^{-1}$; $R f$ - final reading of the water level in the tank, m; $R i$ - initial reading of the water level in the tank, $\mathrm{m} ; D$ - internal diameter of the reservoir, $\mathrm{m} ; \Delta T$ - time interval between readings, and $n$ - number of plants in the profile for the time interval $\Delta T$.

The results were submitted to variance analysis $(\mathrm{p} \leq 0.05)$. When a significant effect was found for the treatments, a breakdown of the degrees of freedom of these treatments was made, and the mean values for each treatment adjusted by a simple linear regression model.

\section{RESULTS AND DISCUSSION}

In Figure 1 are shown the values for electrical conductivity and $\mathrm{pH}$ of the nutrient solution of the treatments being studied.

It can be seen that in treatment 1 (T1), in which the nutrient solution was prepared only with water from the water supply $\left(0.2 \mathrm{dS} \mathrm{m}^{-1}\right)$, there was a decrease in ECsol over time (Figure 1A). It is possible to attribute this to the nutrient consumption of the plants being greater than the accumulation of salts dissolved in the water used for replacement. On the other hand, in the remaining treatments there was a small increase in the salinity of the nutrient solution throughout the cycle due to an accumulation of salts from an increase in the salinity of the water used in preparing the nutrient solution and the absorption of less nutrients with these treatments.

In a study with NFT hydroponics using brackish water for the production of lettuce, Alves et al. (2011), Santos et al. (2010) and Smith et al. (2010) obtained results for electrical conductivity of the nutrient solution throughout the cycle similar to those seen in this study. 
It can be seen that in general the $\mathrm{pH}$ of the nutrient solution varied within a range of 5 to 7.5 (Figure 1B), that is, within a range where the $\mathrm{pH}$ does not adversely influence the crop (Maciel et al., 2012). According to Furlani et al. (1999), variations in $\mathrm{pH}$ of between 4.5 and 7.5 do not affect plant development under hydroponics, however for situations where the acidity is less than 4 , some damage may occur to the cell membrane, and in situations where the alkalinity is greater than 8 , there is a deficiency of some nutrients, such as iron and phosphorus.

The increase in EC values of the nutrient solution reduced the value linearly for each of the variables of growth and yield being analysed (Table 1).

Percentage decreases can be seen of the order of $18,8.05,12.4,12.5,14.6,7,13.4$ and $5.9 \%$ for the variables leaf area, number of leaves, shoot fresh weight and shoot dry weight, absolute growth rate of the shoot fresh and dry weight and relative growth rate of the shoot fresh and dry weight (Table 1).

The reductions in shoot fresh and dry weight seen in this study may be related to the reduction in osmotic potential of the solution resulting in an inadequate supply of nutrients, due to an ionic imbalance caused by an excess of $\mathrm{Na}^{+}$and $\mathrm{Cl}^{-}$ions, as inferred by Tester and Davenport (2003). Similarly, finding a significant effect of water salinity on the variables LA and LN (Table 1) shows that under the conditions of salinity being tested, the crop of Chinese cabbage reduced FMS by a reduction in both the size and number of leaves.

The results for shoot fresh and dry matter found in this study are consistent with those observed by Paulus et al. (2010), who also noted reductions for these variables at the expense of increased salinity of the nutrient solution.

Figure 1 - Mean values for electrical conductivity (A) and pH (B) of the nutrient solution during the experiment at UFRPE in Recife, 2012
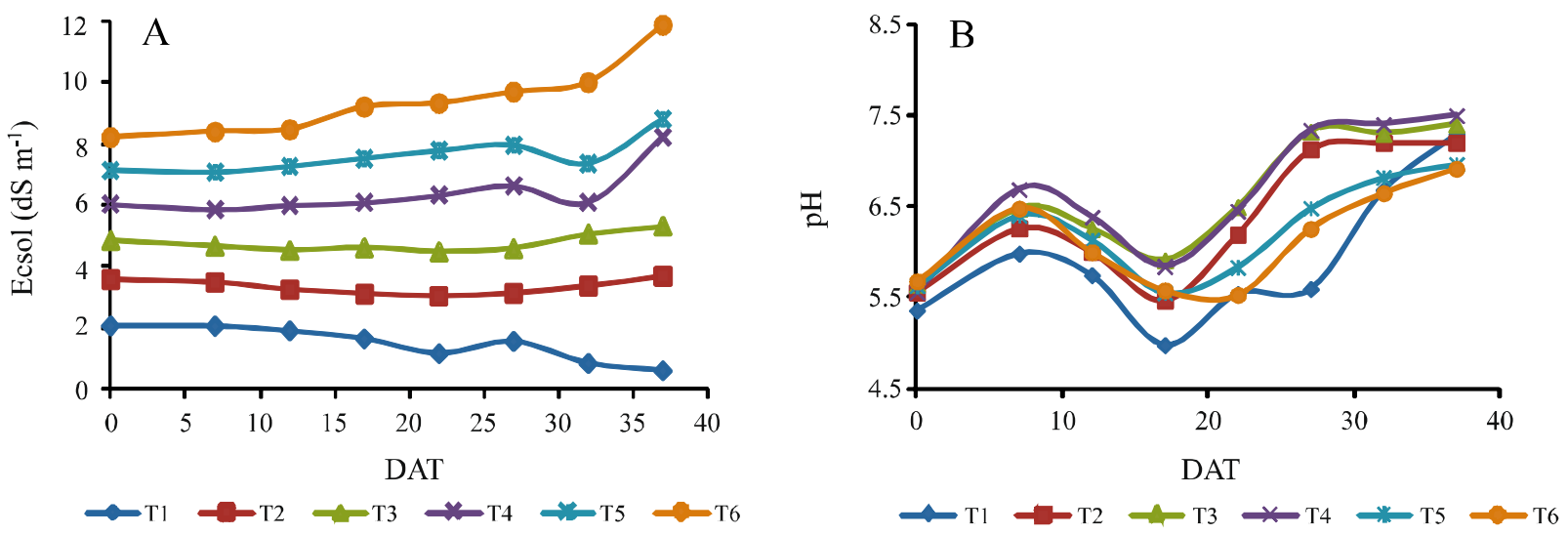

Table 1 - Summary of the variance analysis and regression equations adjusted to the growth and yield variables being analysed, as a function of water salinity - ECw

\begin{tabular}{lcccc}
\hline \multicolumn{1}{c}{ Variable } & F-Test & CV $(\%)$ & Regression Equation & $\mathrm{R}^{2}$ \\
\hline LA & $104.07 * *$ & 14.34 & LA $=16.590-2.986^{* * \mathrm{x}}$ & 0.80 \\
LN & $18.57 * *$ & 9.63 & LN $=27.68-2.228 * * \mathrm{x}$ & 0.84 \\
FMS & $52.12 * *$ & 12.08 & FMS $=793.59-98.59 * * \mathrm{x}$ & 0.89 \\
DMS & $29.87 * *$ & 13.34 & DMS $=63.93-8.015 * * \mathrm{x}$ & 0.95 \\
AGRFM & $107.62 * *$ & 9.24 & AGRFM $=34.05-4.980 * * \mathrm{x}$ & 0.89 \\
RGRFM & $6.11 * *$ & 15.51 & AGRDM $=0.129-0.009 * * \mathrm{x}$ & 0.85 \\
AGRDM & $26.14 * *$ & 16.03 & RGRFM $=2.844-0.382 * * \mathrm{x}$ & 0.93 \\
RGRDM & $2.89 *$ & 17.66 & RGRDM $=0.136-0.008 * * \mathrm{x}$ & 0.86 \\
\hline
\end{tabular}

**and $*$ = respectively, significant at $1 \%$ and $5 \%$ probability; $\mathrm{LA}=$ leaf area; $\mathrm{LN}=$ number of leaves; FMS and DMS = respectively, shoot fresh and dry weight; AGRFM e AGRDM = respectively, absolute growth rate of shoot fresh and dry weight; RGRFM e RGRDM = respectively, relative growth rate of shoot fresh and dry weight 
In their experiments with other leafy vegetables, Silva et al. (2012) and Santos et al. (2010) observed a decline in the number of leaves in the crops being studied, proportional to the salinity of the solution. It is therefore evident that salt stress hinders the development of plants by considerably reducing both the number of leaves and the leaf area, the weight of the shoots, and the fresh and dry weight of the leaves and roots.

The rates for absolute growth of the fresh (AGRFM) and the dry matter (AGRDM) of the shoots and of relative growth of the fresh (RGRFM) and the dry matter (RGRDM) in the Chinese cabbage plants decreased with the increase in water salinity throughout the experiment, and at the lowest water salinity $\left(0.2 \mathrm{dS} \mathrm{m}^{-1}\right)$ resulted in the maximum amount of $33.05 \mathrm{~g} \mathrm{day}^{-1}$ for AGRFM, $2.77 \mathrm{~g} \mathrm{day}^{-1}$ for AGRDM, $0.1272 \mathrm{~g} \mathrm{~g}^{-1} \mathrm{day}^{-1}$ for RGRFM and $0.1344 \mathrm{~g} \mathrm{~g}^{-1}$ day $^{-1}$ for RGRDM (Table 1).

This reduction in the absolute and relative growth rates of the fresh and dry weights of the plant shoots in relation to the salinity of the water may have been due to the decrease in leaf area and greater respiration rate of the plants. According to Taiz and Zeiger (2009), so that they can maintain themselves, plants subjected to salt stress need to divert metabolic energy in an attempt to adapt, which is reflected in reduced $\mathrm{CO}_{2}$ fixation as a result of an inadequate rate of photosynthesis, an increase in breathing due to the condition of stress, a reduction in leaf area and consequently a reduction in the absolute and relative growth rates of fresh and dry weight of the shoots.

Other authors have also emphasized reductions in the absolute and relative growth rates of fresh and dry matter of the shoots in other crops due to salt stress, such as coriander cv. Tabocas e Verdão by Lima (2008), sorghum by Barreto (1997), and maize by Azevedo Neto and Tabosa (2000), these reductions varying depending on the tolerance and sensitivity of the cultivars.

Based on the results obtained for the production of Chinese cabbage using brackish water, it can be inferred that even with a decrease in relative production at the greatest salinity, the possibility exists for the application of this type of water in the production of hydroponic Chinese cabbage. For Paulus et al. (2010) and Paulus et al. (2012), the insignificant use of this water by farmers is due to the lack of information on the feasibility of its use. As an alternative, the producer can compensate for the decrease in relative production by increasing the plant population (ALVES et al., 2011).

Furthermore, the use of this water will enable an increase in agricultural production for those producers who have an available supply of brackish water but a restricted supply of fresh water, reflecting in greater environmental control and the preservation of the fresh water for other purposes.
The increase in salinity of the nutrient solution produced a decreasing lineareffect on the waterconsumption of the Chinese cabbage, with an average water consumption being recorded during the cycle of $579.09 \mathrm{~mL}^{-1 a y^{-1}}$ for the treatment without the use of brackish water $\left(0.2 \mathrm{dS} \mathrm{m}^{-1}\right)$ and of $369.63 \mathrm{~mL} \mathrm{day}^{-1}$ at the greatest salinity $\left(5.2 \mathrm{dS} \mathrm{m}^{-1}\right)$. At the end of the cycle, the total water consumption for the plots where brackish water was not used was $21.52 \mathrm{~L}$ and in the plants subjected to the greatest salinity, this consumption was reduced to $9.71 \mathrm{~L}$ (Figure 2).

According to Figure 2, it can also be seen that the percentage reduction in total water consumption for the crop during the cycle, in relation to the nutrient solution without brackish water, was $10.3 \%$ per unit increase in electrical conductivity of the solution. This reduction may have been a reflection of physiological mechanisms induced by the situation of salt stress, which interfered in the phases of growth and development, reducing water loss by transpiration, as noted by Gomes et al. (2011). Several studies have reported reductions in water consumption in horticultural plants due to increases in the salinity of the nutrient solution (GOMES et al., 2011; PAULUS et al., 2012; SILVA et al., 2012; SOARES et al., 2010).

The levels of leaf nitrogen, potassium, calcium, magnesium, sodium and chloride were significantly affected by the increase in salinity of the solution; but no effect was found for this increase in salinity on the levels of phosphorus or sulphur (Table 2).

Regression analysis showed that an increase in the salinity of the nutrient solution produces quadratic decreases in the leaf concentrations of $\mathrm{N}$ and $\mathrm{K}$ (Figures $3 \mathrm{~A}$ and $3 \mathrm{~B}$ respectively); the minimum levels for leaf nitrogen (22.96 g kg-1) and potassium (4.14 g kg-1) being obtained at an electrical conductivity of 3 and $4.14 \mathrm{dS} \mathrm{m}^{-1}$ respectively.

Figure 2 - Total water consumption for the crop of Chinese cabbage as a function of water salinity - $\mathrm{ECw}$

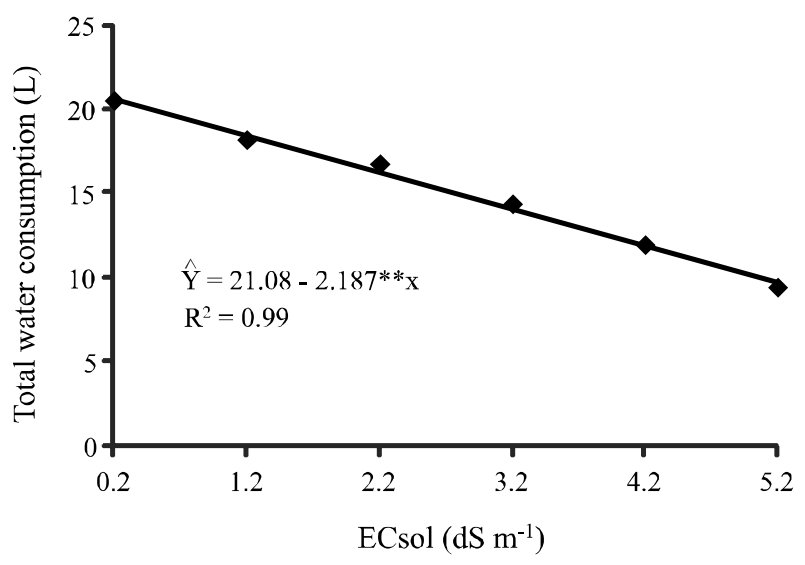


Table 2 - Summary of the variance analysis of the levels of leaf nutrients in Chinese cabbage, as a function of water salinity - ECw

\begin{tabular}{lcc}
\hline \multicolumn{1}{c}{ Variable } & $\mathrm{ECw}-\mathrm{F}$-test & $\mathrm{CV}(\%)$ \\
\hline $\mathrm{N}$ & $6.36^{* *}$ & 10.28 \\
$\mathrm{P}$ & $0.89^{\mathrm{ns}}$ & 12.84 \\
$\mathrm{~K}$ & $12.56^{* *}$ & 12.80 \\
$\mathrm{Ca}$ & $13.88^{* *}$ & 14.64 \\
$\mathrm{Mg}$ & $20.96^{* *}$ & 17.21 \\
$\mathrm{~S}$ & $0.94^{\mathrm{ns}}$ & 17.34 \\
$\mathrm{Na}$ & $11.25^{* *}$ & 17.02 \\
$\mathrm{Cl}$ & $9.18^{* *}$ & 5.55 \\
\hline
\end{tabular}

${ }^{\text {ns }}$ : not significant and $* *$ : significant at $1 \%$ probability; $\mathrm{N}=$ nitrogen; $\mathrm{P}=$ phosphorus; $\mathrm{K}=$ potassium; $\mathrm{Ca}=$ calcium; $\mathrm{Mg}=$ magnesium; $\mathrm{S}=$ sulphur; $\mathrm{Na}=$ sodium $\mathrm{Cl}=$ chloride $; \mathrm{ECw}=$ water salinity; $\mathrm{CV}=$ coefficient of variation

Figure 3 - Levels of leaf nitrogen $(\mathrm{N})$ (a) and potassium (K) (b) in the crop of Chinese cabbage, as a function of water salinity - ECw

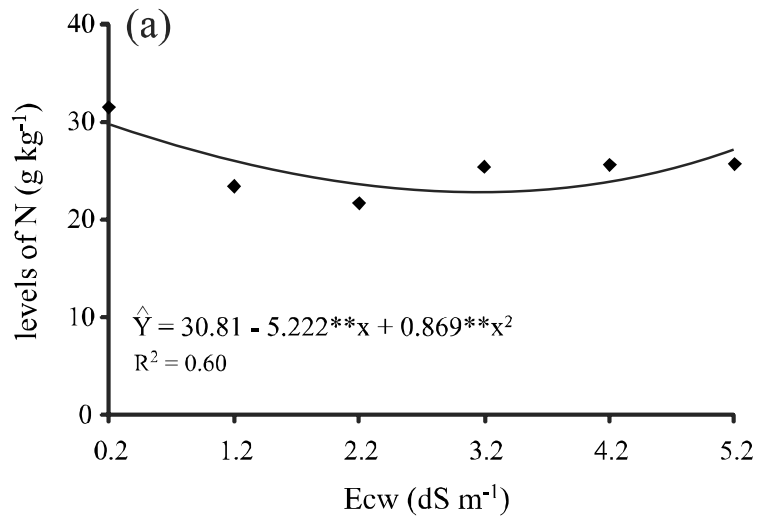

The average value for the level of $\mathrm{N}$ in the leaf $\left(25.58 \mathrm{~g} \mathrm{~kg}^{-1}\right)$ obtained in this work was not within the concentration range (30-55 $\mathrm{g} \mathrm{kg}^{-1}$ ) considered to be adequate for cabbage crops, as established by Silva (1999). This result may reflect the high concentration of salts in the nutrient solution, since, according Debouba et al. (2006), an increase in the salt concentration of the medium may affect the absorption of nitrate $\left(\mathrm{NO}_{3}^{-}\right)$and consequently, leaf nitrate levels. On the other hand, the average value for $\mathrm{K}\left(35.31 \mathrm{~g} \mathrm{~kg}^{-1}\right)$ was within the range considered as adequate $\left(20-40 \mathrm{~g} \mathrm{~kg}^{-1}\right)$.

The results for leaf $\mathrm{N}$ levels obtained in this study differ from those obtained by Paulus et al. (2012) who, when studying nutrient uptake in hydroponic lettuce using saline water, found no significant differences in leaf nitrogen levels due to the increased salinity of the water used to prepare the nutrient solution. The same authors however found a reduction in the absorption of potassium when sodium was added to the nutrient solution, and attributed this to antagonism between the

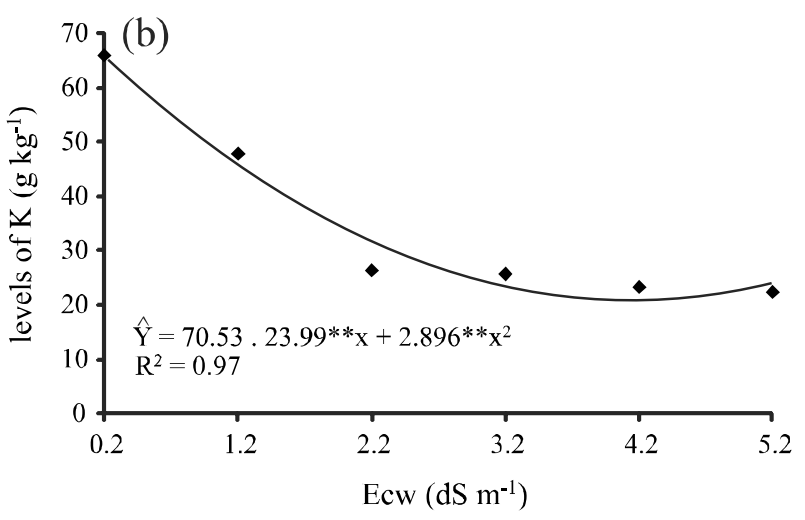

cations. A reduction in the absorption of $\mathrm{K}$ as an effect of the increase in salinity of the nutrient solution was also reported by Gondim et al. (2010) who evaluated electrical conductivities of between 0.5 to $4.0 \mathrm{dS} \mathrm{m}^{-1}$ and found that higher salt concentrations $\left(4.0 \mathrm{dS} \mathrm{m}^{-1}\right)$ contributed to a greater reduction of $\mathrm{K}$ levels in the leaves.

The concentration of magnesium and calcium decreased with the increasing salinity of the water used to prepare the nutrient solution (Figures 4A and 4B respectively). With unit increases in salinity, percentage decreases of the order of $10 \%$ and $12 \%$ can be seen for the levels of $\mathrm{Ca}$ and $\mathrm{Mg}$ in the leaf respectively.

Paulus, Dourado Neto and Paulus (2012), working with a lettuce crop under different salinities, also found that increasing the sodium concentration of the nutrient solution led to reductions in the calcium concentration of the leaves.

The reduction in magnesium concentration of the plants was very similar to that of the concentration 
of $\mathrm{Ca}$ when undergoing the same increments in the sodium chloride concentration of the nutrient solution, with the decreasing linear equation model also being the best fit to the data (Figure 4B).

Concentrations of magnesium may remain constant or decrease in the shoots with an increase in salt stress (PAULUS; DOURADO NETO; PAULUS, 2012). However, Paulus et al. (2012) concluded that this variability in results highlights the importance of further study into the influence of salinity on the concentration of this macronutrient in different plant tissue.

The increase in salinity of the nutrient solution raised the levels of sodium $(\mathrm{Na})$ and chloride $\left(\mathrm{Cl}^{-}\right)$in the leaves (Figure 6A and 6B respectively), with the maximum accumulations of $\mathrm{Na}$ and $\mathrm{Cl}^{-}$in the leaf being obtained at a CEsol of 3.76 and $3.84 \mathrm{dS} \mathrm{m}^{-1}$ respectively, values at which the concentrations of $\mathrm{Na}^{-} \mathrm{and}^{-}$in the leaf began to decrease, possibly indicating a defence mechanism of the plant to the salt stress induced by those elements.

According to Marschner (1995), the chloride displays high mobility and transport as a free anion in the plant.
However, under the conditions of this study, the concentration of $\mathrm{Cl}^{-}$in the leaves of the Chinese cabbage was lower than the concentration of $\mathrm{Na}$ (Figure 5). For Taiz and Zeiger (2009), in general an appropriate level of $\mathrm{Cl}^{-}$in the plant tissue would be from 1,000 to $2.000 \mathrm{mg} \mathrm{kg}^{-1}$ and, according to Marschner (1995), levels over 2,500 mg kg-1 can cause toxicity in sensitive plants.

Although most plants usually absorb $\mathrm{Cl}^{-}$in greater amounts than are necessary for their metabolism (TAIZ; ZEIGER, 2009), the average levels of $\mathrm{Cl}^{-}$found in the leaves of the Chinese cabbage in this work were not classified as being able to cause antagonistic effects in other nutrients, especially the anions, with respect to sulphur and phosphorus, for which no significant difference was seen between the treatments employed.

Analysis of the concentration of nitrogen, phosphorus, potassium, calcium, magnesium and sulphur in the shoots of the Chinese cabbage plants showed that, with the exception of the mean levels for nitrogen, on average, each of the other macronutrients were within the appropriate concentration ranges established for the crop by Silva (1999).

Figure 4 - Levels of leaf calcium (Ca) (a) and magnesium (Mg) (b) in the crop of Chinese cabbage, as a function of water salinity - ECw
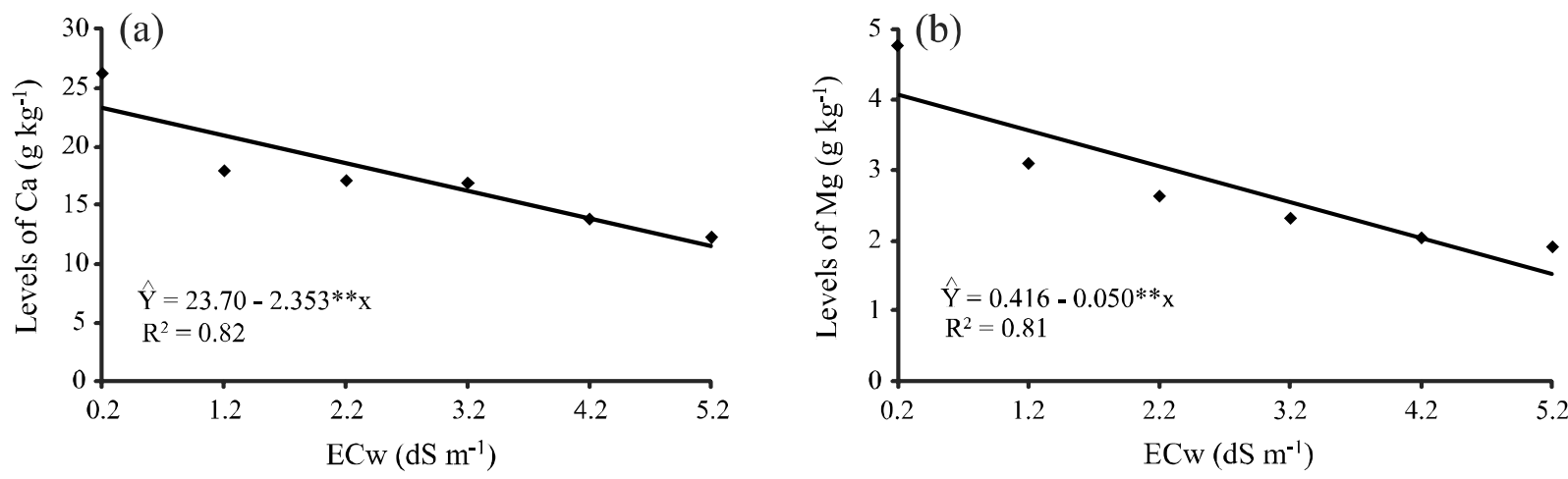

Figure 5 - Levels of leaf sodium (Na) (a) and chloride $(\mathrm{Cl})(\mathrm{b})$ in in the crop of Chinese cabbage, as a function of water salinity - Ecw
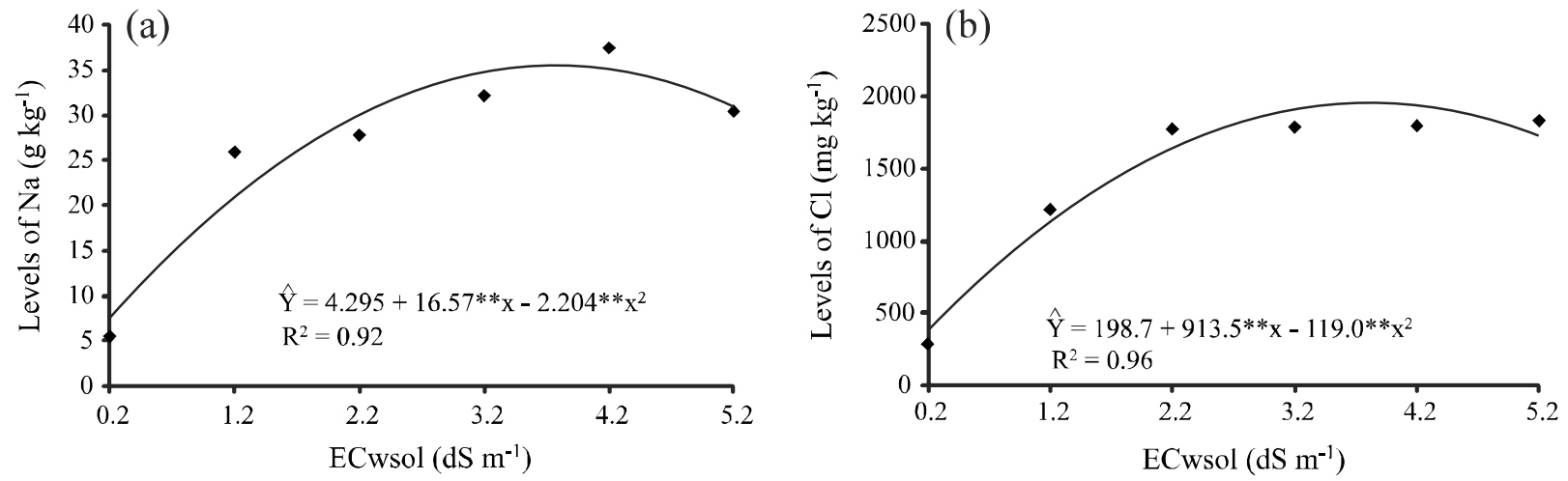
Despite an increase in sodium levels in the leaves to a value of $34.44 \mathrm{~g} \mathrm{~kg}^{-1}$, consumers who buy Chinese cabbage produced at the greatest salinity $\left(5.2 \mathrm{dS} \mathrm{m}^{-1}\right)$ will be ingesting $0.68 \mathrm{~g} \mathrm{Na}$ plant $^{-1}$ and $0.04 \mathrm{~g} \mathrm{Cl}^{-}$plant ${ }^{-1}$, taking into account an estimated weight for shoot dry matter of $22.2 \mathrm{~g} \mathrm{plant}^{-1}$ and shoot fresh matter of $281 \mathrm{~g} \mathrm{plant}^{-1}$ (Table 1). Starting from the principle that the recommended limit is $6 \mathrm{~g} \mathrm{NaCl}$ per day (PAULUS et al., 2012), it can be inferred that the amount of $\mathrm{NaCl}$ accumulated in the leaves of Chinese cabbage under the conditions of this experiment, does not present a risk to consumer health in relation to the levels of $\mathrm{Na}$ and $\mathrm{Cl}^{-}$as measured in the leaves.

\section{CONCLUSIONS}

1. With the exception of the treatment at the lowest salinity, there was tendency in the remaining treatments to increasing electrical conductivity of the nutrient solution with the increasing salinity of the water;

2. The $\mathrm{pH}$ of the nutrient solution remained within the normal range throughout the crop cycle;

3. Water consumption and all the variables of growth and yield being analysed were reduced with the increase in salinity of the water used to prepare the nutrient solution;

4. An increase in salinity of the nutrient solution produced increases in the levels of leaf $\mathrm{Na}$ and $\mathrm{Cl}$ and a reduction in the levels of $\mathrm{N}, \mathrm{K}, \mathrm{Ca}$ and $\mathrm{Mg}$;

5. It is possible to use brackish water in the production of Chinese cabbage grown hydroponically as an alternative for those producers who may have an available supply of brackish water but a restricted supply of fresh water, although with a reduction in productivity.

\section{ACKNOWLEDGEMENTS}

The authors wish to thank the National Council for Scientific and Technological Development (CNPq) and the National Institute of Science and Technology in Salinity (INCTSal) for their financial support of the project. Thanks also go to the Coordination for the Improvement of Personnel in Higher Education (CAPES) and CNPq for granting scholarships.

\section{REFERENCES}

ALVES, M. S. et al. Estratégias de uso de água salobra na produção de alface em hidroponia NFT. Revista Brasileira de Engenharia Agrícola e Ambiental, v. 15, n. 5, p. 491-498, 2011.
ANDRADE JÚNIOR, A. S. et al. Uso e qualidade da água subterrânea para irrigação no semi-árido piauiense. Revista Brasileira de Engenharia Agrícola e Ambiental, v. 10, n. 4, p. 873-880, 2006.

AZEVEDO NETO, A. D; TABOSA, J. N. Estresse salino em plântulas de milho: parte II distribuição dos macronutrientes catiônicos e suas relações com sódio. Revista Brasileira de Engenharia Agrícola e Ambiental, v. 4, n. 2, p. 165-171, 2000.

BARRETO, L. P. Estudo nutricional e bioquímico do sorgo (Sorghum bicolor Moench L.) sob estresse salino. 1997. 179 f. Tese (Doutorado em Botânica) - Universidade Federal de Pernambuco, Recife, 1997.

BENINCASA, M. M. P. Análise de crescimento de plantas: noções básicas. Jaboticabal: FUNEP, 1988. 41 p.

BEZERRA NETO, E; BARRETO, L. P. Análises químicas e bioquímicas em plantas. Recife: UFRPE, 2011. 267 p.

DEBOUBA, M. et al. $\mathrm{NaCl}$ stress effects on enzymes involved in nitrogen assimilation pathway in tomato "Lycopersicon esculentum" seedlings. Journal of Plant Physiology, v. 163, n. 12 , p. $1247-1258,2006$.

EVANGELISTA, R. M. et al. Qualidade de couve-chinesa minimamente processada e tratada com diferentes produtos. Ciência e Tecnologia de Alimentos, v. 29, n. 2, p. 324-332, 2009.

FURLANI, P. R. Hydroponic vegetable production in Brazil. Acta Horticulturae, v. 2, n. 481, p. 777-778, 1999.

FURLANI, P. R. Instruções para o cultivo de hortaliças de folhas pela técnica de hidroponia NFT. Campinas: IAC, 1998. 30 p. (Boletim Técnico, 168).

GOMES, J. W. S. et al. Crescimento e produção de tomate cereja em sistema hidropônico com rejeito de dessalinização. Revista Ciência Agronômica, v. 42, n. 4, p. 850-856, 2011.

GONDIM, A. R. O. et al. Condutividade elétrica na produção e nutrição de alface em sistema de cultivo hidropônico NFT. Bioscience Journal, v. 26, n. 6, p. 894-904, 2010.

GORDIN, C. R. B. et al. Níveis de fertirrigação nas características morfofisiológicas de couve chinesa. Revista Agrarian, v. 3, n. 10, p. 253-260, 2010.

HOSSAIN, M. M;NONAMI, H. Effect of salt stress on physiological response of tomato fruit grown in hydroponic culture system. Horticultural Science (Prague), v. 39, n. 1, p. 26-32, 2012.

LIMA, A. B. Respostas fisiológicas e bioquímicas de cultivares de coentro (Coriadrum sativum L.) submetidas ao estresse salino. 2008. 55 f. Dissertação (Mestrado em Botânica) - Universidade Federal de Pernambuco, Recife, 2008.

MACIEL, M. P. et al. Produção de girassol ornamental com uso de águas salobras em sistema hidropônico NFT. Revista Brasileira de Engenharia Agrícola e Ambiental, v. 16, n. 2, p. 165-172, 2012.

MARSCHNER H. Mineral nutrition of higher plants. $2^{\text {a }}$ ed. London: Academic Press, 1995. 889 p. 
PAUlUS, D.; DOURADO NETO, D.; PAULUS, E. Análise sensorial, teores de nitrato e de nutrientes de alface cultivada em hidroponia sob águas salinas. Horticultura Brasileira, v. 30, n. 1, p. $18-25,2012$.

PAULUS, D. et al. Crescimento, consumo hídrico e composição mineral de alface cultivada em hidroponia com águas salinas. Revista Ceres, v. 59, n. 1, p. 110-117, 2012.

PAULUS, D. et al. Produção e indicadores fisiológicos de alface sob hidroponia com água salina. Horticultura Brasileira, v. 28, n. 1, p. 29-35, 2010.

SANTOS, A. N. et al. Cultivo hidropônico de alface com água salobra subterrânea e rejeito da dessalinização em Ibimirim, PE. Revista Brasileira de Engenharia Agrícola e Ambiental, v. 14, n. 9, p. 961-969, 2010.

SANTOS, A. N. et al. Produção de alface em NFT e Floating aproveitando água salobra e o rejeito da dessalinização. Revista Ciência Agronômica, v. 42, n. 2, p. 319-326, 2011.

SILVA, A. O. et al. Consumo hídrico da rúcula em cultivo hidropônico NFT utilizando rejeitos de dessalinizador em Ibimirim-PE. Irriga, v.17, n. 1, p. 114-125, 2012.
SILVA, F. C. (Org.). Manual de análises químicas de solos, plantas e fertilizantes. Brasília, DF : Embrapa Comunicação para Transferência de Tecnologia, 1999. 370 p.

SOARES, T. M. et al. Combinação de águas doce e salobra para a produção de alface hidropônica. Revista Brasileira de Engenharia Agrícola e Ambiental, v. 14, n. 7, p. 705-714, 2010.

SOARES, T. M. et al. Economic risk analysis of tomato irrigation using desalinated water by reverse osmosis. Irrigation and Drainage, v. 62, n. 5, p. 658-665, 2013.

SOARES, T. M. et al. Experimental structure for evaluation of brackish water use in lettuce hydroponic production. Irriga, v. 14, n. 1, 102-114, 2009.

SOARES, T. M. et al. Produção de alface utilizando águas salinas em sistema hidropônico. Irriga, v. 12, n. 2, p. 235248, 2007.

TAIZ, L; ZEIGER, E. Fisiologia vegetal. 4 ed. Porto Alegre: Artmed, 2009. 819 p.

TESTER, M.; DAVENPORT, R. $\mathrm{Na}^{+}$tolerance and $\mathrm{Na}^{+}$transport in higher plants. Annals of Botany, v. 91, n. 5, p. 503-527, 2003. 